Ксенія Єргідзей

Національний університет оборони України імені Івана Черняховського

ORCID ID 0000-0003-4634-133X

\title{
ФОРМУВАННЯ ПЕДАГОГІЧНОГО ІМІДЖУ МАЙБУТНЬОГО ВИКЛАДАЧА ВИЩОГО ВІЙСЬКОВОГО НАВЧАЛЬНОГО ЗАКЛАДУ
}

Стаття присвячена формуванню педагогічного іміджу майбутнього викладача вищої військової школи, розглянуто наукові підходи до його розуміння. Визначено сутність та зміст професійного іміджу викладача вищого військового навчального закладу. Визначено етапи формування педагогічного іміджу майбутнього викладача вищої військової школи.

Ключові слова: імідж військового викладача; вищий військовий навчальний заклад; професійне становлення майбутнього викладача.

Постановка проблеми. Сучасні збройні сили України переживають складний період реформування. Трагічні події на сході країни змусили глянути на армію не тільки як на збройну силу, але і як на вірного зберігача ідей служіння батьківщині, патріотизму, громадянської відповідальності за долю держави. Все це сприяло перегляду ставлення до системи моральнопсихологічного педагогічного забезпечення підготовки офіцерів, створення оновленої системи військової освіти, обгрунтування механізмів його функціонування і реалізації. У зв'язку з цим у вирішенні завдань підготовки військових фахівців особливого значення набуває особистість офіцеравихователя і викладача вищого військового навчального закладу (ВВНЗ). Успішне здійснення військовим викладачем складних завдань підготовки сучасного фахівця неможливо без обліку рівня розвитку його іміджу. Таким чином, виникло протиріччя між потребами практики i відсутністю теоретичної і емпіричної обгрунтованості ефективної системи забезпечення підготовки військового фахівця [6].

Аналіз останніх досліджень. Дослідженню проблеми іміджу присвячено роботи зарубіжних учених П. Берда, Л. Брауна, Ф. Тейлора, А. Файоля. Сутність професійного іміджу фахівця та особливості його ефективної самопрезентації розглядали I. Альохін, В. Бебік, Ф. Кузін, Д. Френсіс. Проблеми формування іміджу педагогів вивчали О. Бекетов, Л. Жаріков, Т. Зеленська, А. Калюжний, Г. Почепцов. Питаннями становлення особистості офіцера у ВВНЗ і вдосконалення військовопрофесійної, педагогічної, психологічної підготовки військових викладачів присвячено значну кількість досліджень А. Вітченка, В. Осьодла, О. Хміляра, В. Ягупова. Окремі аспекти створення професійно-педагогічного іміджу викладача вищої школи розробляли Н. Гузій, О. Ковальова, А. Морозов, І. Ханіна.

Аналіз літератури 3 проблеми дослідження дозволяє зробити висновок про те, що, незважаючи на наявні роботи по військовій педагогіці, присвячені 
професійному розвитку особистості викладача, аспект, що передбачає створення ефективної системи формування професійного іміджу майбутніх військових педагогів, розкрито недостатньо повно і потребує в додатковому дослідженні.

В результаті теоретичного аналізу наукової літератури 3 проблеми формування іміджу військового викладача нами були виявлені зарубіжні та вітчизняні концепції, проаналізовано їх переваги та недоліки, визначено форми, методи, етапи та засоби його формування. Встановлено, що в сучасній науці існує різноманіття підходів до визначення самого поняття "професійний імідж", сутності і специфіки цього складного психологопедагогічного феномена.

Метою статті $\epsilon$ узагальнення існуючого уявлення про імідж викладача вищої військової школи. Важливим є обгрунтування необхідності створення правильного, позитивного іміджу для майбутнього викладача вищої військової школи.

Виклад основного матеріалу. Масштабні зміни в суспільній структурі країни, політичних, економічних та соціокультурних процесах, модернізація військової освіти, рух до НАТО висувають нові вимоги до рівня професійних знань, умінь, педагогічної культури, особистісних і професійних якостей викладача вищої військової школи. Створення привабливого педагогічного іміджу дасть змогу військовому педагогу отримати визнання у слухацькій аудиторії, закласти фундамент для здобуття авторитету, мотивувати себе на успіх, відчувати впевнено й досягати позитивних результатів у педагогічній діяльності.

Розгляд педагогічного іміджу майбутнього викладача вищої військової школи як чинника ефективної професійної діяльності призводить до необхідності більш глибокого аналізу поняття «імідж викладача вищої військової школи». Як зазначає О. Красницька, педагогічний імідж викладача вищого військового навчального закладу - це емоційно забарвлений образ педагога, що складається на основі його зовнішнього вигляду, особистісних та професійних якостей, професійної компетентності, педагогічної культури та ораторської майстерності [4]. В умовах університету імідж формується на основі прямого контакту слухача 3 викладачем - це така інтегральна характеристика, яка містить в собі сукупність зовнішніх i внутрішніх, особистісних, індивідуальних та професійних якостей педагога i сприяє ефективності педагогічної діяльності. Досягнення такої гармонійної сукупності якостей вимагає від викладача усвідомленості дій, що в свою чергу неможливо без рефлексії. 3 іншого боку, щоб відрефлексувати свої характеристики, педагогу необхідно знати які вимоги пред'являе йому слухацька аудиторія і колеги. Теорія та практика іміджу в системі освіти суттєво розкриває питання про те, якими якостями повинні володіти учасники педагогічного процесу для самоствердження в суспільстві. За результатами багатьох наукових досліджень професійного іміджу педагога, вихідною позицією постають реальні люди зі своїми потребами, цінностями, 
прагненнями та відповідними якостями. За даними О. Володарської [2] i М. Пискунова [5] окремі якості $\epsilon$ найбільш значущі для професійної педагогічної діяльності. До них можна віднести: ввічливість, вдумливість, вихованість, ерудованість, передбачливість, уважність, витримку, гнучкість поведінки, гуманність, щирість, діловитість, дисциплінованість, скромність, тактовність, культуру мови, прагнення до самовдосконалення, почуття гумору та інші. Натомість, важливо погодитися з авторами у тому, що всі перераховані якості є значущими для формування іміджу педагога. Можна припустити, що серед них провідними виступають: культура мови, гнучкість поведінки, справедливість, почуття гумору, відповідальність, передбачливість, впевненість, емоційна стійкість, емпатійність, самоконтроль. Ураховуючи достатньо великий перелік ознак позитивного іміджу педагога, ми зробили спробу їх систематизувати. До ознак особистісного спрямування, виходячи зі специфіки педагогічної діяльності, можна віднести: інтелектуальний потенціал, цілеспрямованість, рішучість, емоційність, силу волі, відвертість, наявність почуття гумору, інтуїцію в ухваленні рішень. До ознак професійно-спеціалізованих відносимо володіння ораторським мистецтвом, уміння уникати конфлікти, уміння сперечатися, відповідність обіцянок вчинкам, хазяйновитість, працьовитість, відкритість в спілкуванні, вміння взаємодіяти 3 органами влади, професійний досвід. Соціально визначені ознаки об'єднують популярність, респектабельність, частоту згадування в засобах масової інформації, правильний спосіб життя, прихильність до спорту, сімейність, зовнішній вигляд, матеріальне благополуччя. Щодо технологічних ознак, які можуть відобразити різні прийоми та методи, то варто зазначити, що вони й до теперішнього часу залишаються недостатньо вивченими і уточненими. На наш погляд, поза увагою дослідників іміджу залишається також його особистісний аспект, оцінка значимості, створення якої відбувається в рефлексії культури професійної діяльності педагога. Ситуативна тривожність, страх показатися смішним, виявити свою некомпетентність, бути негативно оціненим уповільнюють процеси творчого саморозвитку як педагога, так і вихованця. Без розвиненої внутрішньої рефлексії, усвідомлення витоків свого негативного переживання педагог не може переключитися на світ іншої людини (колег, курсантів, студентів), побачити їх проблеми своїми очима. Визначаючи, яким повинен бути індивідуальній імідж викладача вищого військового навчального закладу, здатного реалізувати завдання становлення особистості слухача та враховуючи зазначене вище, відмітимо, що це має бути високоморальна особистість з гуманістичними рисами, які виявляються в його поведінці, вчинках, мові, в професійній діяльності, зовнішньому вигляді, дисципліні та інше. В педагогічній діяльності імідж викладача - це умова, засіб становлення індивідуальності обох суб' єктів навчання.

Таким чином, являючи собою систему взаємопов'язуючих характеристик фахівця, імідж стає засобом вирішення особистих i професійних проблем. Більшість дослідників відмічають, що сучасний імідж 
є складовою культури ділового спілкування. В ньому зацікавлені представники будь-якої публічної професії. Водночас не всі педагоги мають уявлення про те, як сформувати свій індивідуальний імідж. Він як динамічна характеристика, яка знаходиться в постійній взаємодії суб'єкта - власника іміджу - 3 оточенням (соціальним, природним, культурним), формується i розвивається в процесі професійної діяльності та безперервного самовдосконалення. Зрозуміло, що процес самовдосконалення у цьому напрямі потребує певних особистих зусиль, матеріальних затрат, але ми переконані, що це матиме позитивну віддяку. Створення іміджу - це підкреслення особистої індивідуальності, свідомого вибору певного образу. Формування іміджу - поетапний i довготривалий процес, ефективність створення якого зумовлена рядом умов. Насамперед, це наявність у майбутнього викладача інтересу до себе i до світу, усвідомлення необхідності формування позитивного іміджу; прояв власної активності при роботі над ним. Не менш важливими є знання вимог слухацької аудиторії до особистості та діяльності викладача; оволодіння прийомами самопізнання i самооцінювання, а також навичками самопрезентації i проектування індивідуального іміджу; дотримання принципу різноманіття форм і методів роботи з формування і корекції іміджу.

На нашу думку, щоб сформувати позитивний педагогічний імідж майбутньому викладачу вищої військової школи, найперше, необхідно працювати над зовнішнім виглядом, розвивати культуру мовлення, культуру спілкування, харизматичність, особистісні та професійні якості ораторські уміння. Майбутньому викладачу необхідно розуміти, що створення привабливого іміджу - довготривалий і багатогранний процес, у якому немає дрібниць.

Пропонуємо пройти такі етапи його формування і вдосконалення:

1. Намалювати свій новий портрет - скласти образ нового «Я» - яким я хочу стати.

2. Продіагностувати себе - якості, здібності, уміння. Визначити свої переваги та недоліки. Отримати зворотній зв'язок від близьких, друзів, підлеглих, колег. Визначити, над чим необхідно працювати.

3. Скласти програму особистісного й професійного самовдосконалення.

4. Реалізація програми. Організація свого життя в узгодженні 3 новим «Я». Порівняння запланованих результатів із тими, що реально досягаються. Внесення коректив у програму.

5. Аналіз досягнутих результатів. Постановка нових цілей. [7]

Підсумовуючи вищесказане, зазначимо. По-перше, позитивний імідж викладача вищої військової школи, що складається насамперед 3 професіоналізму (мистецтва володіння знаннями 3 предмета, педагогічними технологіями, психологічною грамотністю) та адаптованість поряд із рішучістю є ключем до успіху у викладацькій діяльності. По-друге, імідж це сполучення науки та мистецтва, яке надає креативні можливості для 
кожного. Правильно сформований позитивний імідж працює на викладача, полегшує його професійну діяльність, робить його особистість неповторною.

Висновки. Презентуючи власний імідж, викладач демонструє слухачам (курсантам, студентам) себе як особистість професіонала, своє ставлення до навколишніх, очікування від інших. Правильно сформований імідж, уміння самопрезентації не лише полегшують досягнення стратегічних цілей, але й впливають на формування особистого іміджу слухачів (курсантів, студентів) і вищого військового навчального закладу загалом.

На основі підходів Г. Почепцова, В. Шепеля, О. Красницької педагогічний імідж викладача вищої військової школи визначено як емоційно забарвлений образ педагога, що складається на основі його зовнішнього вигляду, особистісних та професійних якостей, професійної компетентності, педагогічної культури та ораторської майстерності. Процес формування педагогічного іміджу $є$ складним, що пояснюється впливом сукупності факторів: можливостей педагога, потреб освітніх завдань, особливостей інформаційних каналів та задоволеності учасників освітнього процесу. Досліджено, що побудова іміджу викладача відбувається свідомо та цілеспрямовано, тому цей процес потребує постійного управління ним, що передбачає конструювання позитивного образу педагога, імплементацію бажаних характеристик у його поведінкову форму, мотиваційно-ціннісну спрямованість та комплексну систему оцінювання.

\section{ЛІТЕРАТУРА}

1. Вітченко А.О. Осьодло В.І., Салкуцан С.М., та інші Технології навчання у вищій військовій школі: теорія і практика : навч.-метод. посіб. Київ, НУОУ, 2016. 272 с.

2. Володарская Е. А. Социально-психологический анализ научной школы в имиджелогии. Имиджелогия-2005: феноменология, теория, практика : Материалы Третьего международного симпозиума Москва : РИЦ АИМ, 2005. С.40-42.

3. Козлова О. Г. Відображення особистісно-професійного іміджу вчителя у феномені педагогічної майстерності. Постметодика, 2012.

4. Красницька О.В. Імідж викладача вищого військового навчального закладу. Педагогічна наука в Україні за роки незалежності: здобутки, прорахунки, перспективи : матеріали всеукр. (з міжнар. участю) наук.-практ. конф., м. Херсон, 15-16лист. 2017 р. Херсон, 2017. С. 237-240.

5. Пискунов М. С. Имидж образовательного учреждения: структура и механизмы формирования. Мониторинг и стандарты в образовании. 1999. № 5. С. 5-9.

6. Рябинов А. Н., Петьков В.А.Становление авторитета военного педагога: проблемы и перспективы: монография. Москва, 2003. 179 с.

7. Хміляр О.Ф., Красницька О.В., Недвига О.В. Теорія і практика відбору персоналу : навч. посіб. Київ : ЦП «Компринт», 2018. 303 с.

8. Ягупов В. В. Педагогіка : навч. посібник. Київ : Либідь, 2002. 560 с.

\section{REFERENCES}

1. Vitchenko, A.O. (2016) Tehnologizaciya navchannya y vishiy viyskoviy shkoli: teoriya i practika: navch.-metod. posib. [Technologies of studies at higher military school]. K., NYOU, 272 s. (in Ukrainian). 
2. Volodarskaya, E.A. (2005) Socialno-psihologicheskiy analiz nauchnoy shkoli v imidjeologii [Socially-psychological analysis of scientific school in image science]. Materiali Tretjego mejdunarodnogo simpoziyma, M., RIC AIM, S.40-42. (in Russian).

3. Kozlova, O.G. (2012) Vidobrajennya osobistnisno-profesiynogo imidgy vchitelya y fenomeni pedagogichnoy majisternosti [A reflection of personality-professional image of teacher in the phenomenon of pedagogical mastery]. Postmetodika. (in Ukrainian).

4. Krasnicka, O.V. (2017) Imidg vikladacha vishogo vijskovogo navchalnogo zaklady. [Image of the future teacher of higher military education institution]. Pedagogichna nauka $\mathrm{V}$ Ukraine za roki nezalegnosti: zdobytki, prorahynki, perspektivi: materiali vseukr. (z mignar. ychastu) nayk.-prakt. konf., m. Herson, S. 237-240. (in Ukrainian).

5. Piskunov, M.S. (1999) Imidg obrazovatelnogo ychregdeniya: struktura i mehanizmi formirovaniya [Image of educational establishment : structure and forming mechanisms]. Monitoring i standarti v obrazovanii, № 5, S. 5-9. (in Russian).

6. Rjabinov, A.N., Petkov, V.A. (2003) Stanovlenie avtoriteta voennogo pedagoga: problemi i perspektivi: monografiya [Becoming of authority of military teacher : problems and prospects]. M., 179 s. (in Russian).

7. Hmilar, O.F., Krasnicka, O.V., Nedviga, O.V. (2018) Teoriya i praktira vidbory personaly: navch. posib. [Theory and practice of selection of personnel]. K., CP «Komprint», 303 c. (in Ukrainian).

8. Yagypov, V.V. (2003) Pedagogika: Navch. posibnik. [Pedagogics]. K., Libid, 560 s. (in Ukrainian).

\title{
РЕЗЮМЕ
}

Ксения Ергидзей

Национальный университет обороны Украины имени Ивана Черняховского

\section{Формирование педагогического имиджа будущего преподавателя высшего военного учебного заведения}

Статья посвящена формированию педагогического имиджа будущего преподавателя высшей военной школы, рассмотрены научные подходы к его пониманию. Определена сущность и содержание профессионального имиджа преподавателя высшего военного учебного заведения. Определены этапы формирования педагогического имиджа будущего преподавателя высшей военной школь.

Ключевые слова: имидж военного преподавателя; высшее военное учебное заведение; профессиональное становление военного преподавателя.

\section{SUMMARY}

\author{
Kseniya Yerhidzei \\ National defense University of Ukraine named \\ after Ivan Chernyakhovskiy
}

\section{Formation of pedagogical image of the future teacher of higher military education institution}

Introduction. When solving the task of military specialists' preparation, the personality of the education officer and teacher of a higher military education institution is of particular importance. It is impossible to succeed in the fulfillment of the complex task of a contemporary specialist preparation without taking into consideration the level of their image development. Thus, there is a contradiction between practical needs and the absence of theoretical and empirical grounds for an effective system of a military specialist preparation. 
Purpose. The purpose of the article is the synthesis of the existing view on teacher's image in military higher education institution. It is important to substantiate the necessity of creating a correct, positive image for a future higher military education professor.

Methods. The method of the research is the theoretical analysis of the problem of forming a pedagogical image of a future higher military education professor.

Results. By presenting their own image, the professor shows to the audience (cadets, students) their personality as a professional, their attitude towards the surrounding, and their expectations of others. Not only do a correctly formed image and self-presentation skills simplify the achievement of strategic goals, but also influence the formation of the personal image of both the audience (cadets, students) and the higher military education institution itself.

Originality. The originality of the article lies in defining the stages of the formation of the pedagogical image of the future higher military education professor. The article presents five stages of the formation and enhancement of an attractive image.

Conclusion. The process of pedagogical image formation is intricate, which can be explained by the influence of several factors combination: the abilities of an educator, the requirements of education tasks, the peculiarities of information channels and the satisfaction of the education process participants. It is discovered that the establishment of a teacher's image happens consciously and purposefully, therefore this process calls for constant control over it, which presupposes the construction of a positive teacher's image, the implementation of desired characteristics into their behavioral form, value-motivated orientation and a complex assessment system.

Keywords: image of the military teacher; military higher education institution; professional formation of the military teacher. 